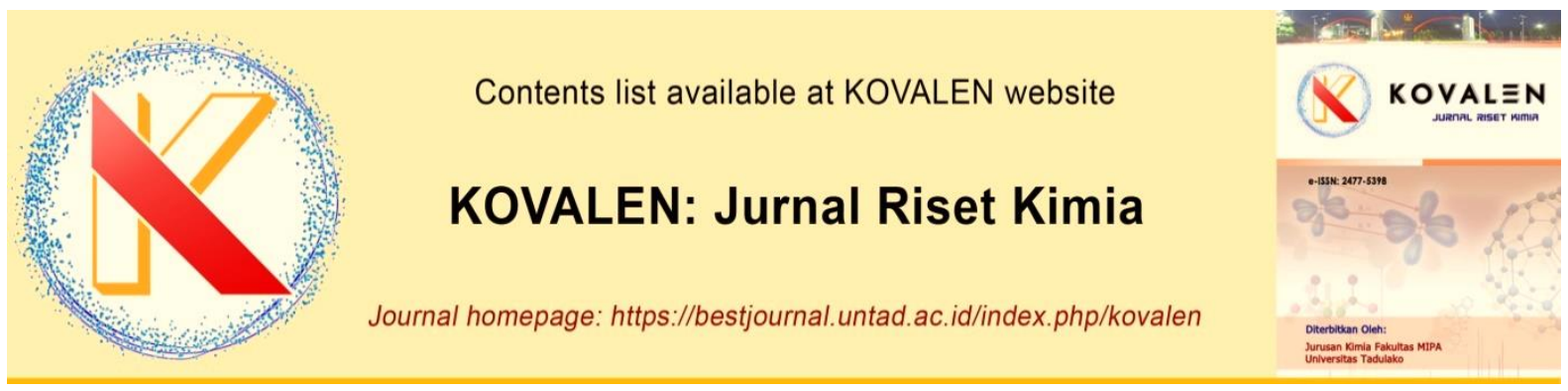

\title{
Ekstraksi dan Uji Stabilitas Zat Warna Alami dari Bayam Merah (Alternanthera amoena Voss)
}

\section{[Extraction and Stabilization of Natural Dyes from Red Spinach (Alternanthera amoena Voss)]}

\author{
Khairuddin, Joy Noldy Baciang*, Indriani, Nov Irmawati Inda \\ Jurusan Kimia, Fakultas Matematika dan Ilmu Pengetahuan Alam, Universitas Tadulako, \\ Jl. Soekarno-Hatta Km. 9, Kampus Bumi Tadulako, Palu, Indonesia \\ ${ }^{*}$ Corresponding author: joy_noldy@yahoo.com
}

\begin{abstract}
Research on the extraction and stability test of natural dye from red spinach (Alternanthera amoena Voss) has been carried out. This study aims to determine the effect of $\mathrm{pH}$ and length of sun exposure on the stability of the dye from red spinach. Extraction using the maceration method with ethanol solvent and measurement using a UV-Vis spectrophotometer. Stability testing is carried out at pH 2-5 and sun exposure for 1-4 hours using a dark and light container. The results obtained, at $\mathrm{pH} 2$ and $\mathrm{pH} 3$, anthocyanins were more stable, compared to $\mathrm{pH} 4$ and 5 which had greater color degradation. In exposure to sunlight, dark containers with a degradation percentage of $31.70 \%$ were better than clear containers with a percentage of $48.78 \%$.
\end{abstract}

Keywords: Anthocyanin, red spinach, natural dyes stability.

ABSTRAK. Penelitian tentang ekstraksi dan uji stabilitas zat warna alami dari bayam merah (Alternanthera amoena Voss) telah dilakukan. Penelitian ini bertujuan untuk mengetahui pengaruh $\mathrm{pH}$ dan lama penyinaran matahari terhadap stabilitas zat warna dari bayam merah. Ekstraksi menggunakan metode maserasi dengan pelarut etanol dan pengukuran menggunakan spektrofotometer UV-Vis. Pengujian stabilitas dilakukan pada pH 25 dan paparan sinar matahari selama 1-4 jam dengan menggunakan wadah gelap dan terang. Hasil yang di peroleh, pada $\mathrm{pH} 2$ dan $\mathrm{pH} 3$, antosianin lebih stabil dibandingkan dengan $\mathrm{pH} 4$ dan 5 yang degradasi warnanya lebih besar. Pada paparan sinar matahari, wadah gelap dengan persentasi degradasi yaitu $31,70 \%$ lebih baik dibandingkan wadah bening dengan persentasi $48,78 \%$.

Kata kunci: Antosianin, bayam merah, stabilitas zat warna alami.

Riwayat artikel: Diterima 26 September 2019, Disetujui 2 Desember 2020

Cara sitasi: Khairuddin., Baciang, J N., Indriani., \& Inda, N I. (2020). Ekstraksi dan Uji Stabilitas Zat Warna Alami dari Bayam Merah (Alternanthera amoena Voss). KOVALEN: Jurnal Riset Kimia, 6(3): 212-217.

DOI: https://doi.org/10.22487/kovalen.2020.v6.i3.13670

\section{LATAR BELAKANG}

Pada saat ini, bahan pewarna sintetik banyak digunakan untuk meningkatkan nilai pangan atau nilai jual suatu produk. Pewarna sintetik banyak digunakan dalam berbagai industri seperti tekstil, makanan, dan obatobatan. Penggunaan pewarna sintetik cukup tinggi karena harga yang relatif terjangkau dan mudah untuk didapatkan. Namun demikian pewarna sintetik dapat berakibat tidak baik 
terhadap kesehatan dan lingkungan (Jenie et al., 1994).

Senyawa antosianin dapat dimanfaatkan sebagai pewarna alami yang dapat diaplikasikan pada produk pangan maupun non pangan. Pewarna alami berpotensi untuk mengurangi bahkan menggantikan penggunaan pewarna sintetis yang dilarang pemerintah untuk diaplikasikan pada produk pangan karena bersifat karsinogenik. Beberapa jenis tanaman yang dapat dimanfaatkan sebagai pewarna antara lain buah bit, buah naga, bunga rosella, kayu secang, ubi ungu dan bayam merah (Pratiwi, 2017).

Ekstraksi antosianin dari tanaman telah banyak dilakukan. Antosianin memiliki sifat polar, sehingga pelarut yang cocok digunakan untuk ekstraksi zat tersebut adalah pelarut organik yang bersifat polar juga. Pelarut polar antara lain etanol, metanol, asam format dan air yang dikenal sebagai pelarut universal. Selain tingkat kepolaran pelarut, beberapa hal yang harus dipertimbangkan dalam memilih pelarut adalah pelarut aman untuk digunakan, harganya murah, mudah diperoleh atau ketersediaannya melimpah, bereaksi netral, dan tidak mempengaruhi zat ekstrak.

Kandungan senyawa metabolit sekunder pada bayam merah didominasi atas antosianin, sehingga dapat dijadikan sebagai sumber pewarna dengan aktivitas antioksidan yang dapat menghambat radikal bebas (Syaifuddin, 2015). Zat pewarna alami antosianin merupakan senyawa flavonoid yang tergolong ke dalam turunan benzopiran. Struktur utama turunan benzopiran ditandai dengan adanya dua cincin aromatik benzena $\left(\mathrm{C}_{6} \mathrm{H}_{6}\right)$ yang dihubungkan dengan tiga atom karbon yang membentuk cincin (Moss, 2002). Antioksidan dapat digunakan di berbagai macam bidang, seperti bidang pangan dan industri famasi, industri tekstil (Bangee et al., 1995), perminyakan (Pan et al., 1998) dan industri karet (Pushpa et al., 1995). Eksplorasi tanaman yang mengandung antosianin tinggi terus dilakukan. Salah satu tanaman yang mengandung antosianin tinggi adalah beras hitam. Dari penelitian Kristamtini et al. (2014) diketahui bahwa kadar antosianin dari 11 kultivar padi beras hitam di Indonesia berkisar antara $50-600 \mathrm{mg} / 100 \mathrm{~g}$.

Pigmen antosianin larut dalam air dan memiliki warna merah muda, merah, ungu, biru, dan kuning. Kerangka dasar antosianin berasal dari kation flavilium (Akhda, 2009). Penelitian tentang ekstraksi antosianin pada tanaman banyak dilakukan menggunakan metode maserasi. Hasil penelitian Suzery et al. (2010) menunjukkan bahwa ekstraksi dengan metode maserasi pada suhu kamar memberikan hasil penyarian antosianin yang lebih tinggi dibanding maserasi pada suhu $5^{\circ} \mathrm{C}$ pada bunga rosella. Stabilitas pigmen antosianin dipengaruhi oleh beberapa faktor terutama cahaya matahari (intensitas), suhu udara, dan $\mathrm{pH}$. Setiap jenis tanaman akan menghasilkan kestabilan pigmen yang berbeda karena komponen kimi yang juga berbeda, sehingga stabilitas pigmen bayam merah perlu diteliti terutama terhadap faktor cahaya dan $\mathrm{pH}$.

\section{METODE PENELITIAN}

\section{Bahan dan Peralatan}

Bahan yang digunakan adalah daun bayam merah, etanol $96 \%$, kertas saring, aluminium foil, akuades, buffer $\mathrm{pH} 2,3,4$, dan 5 .

Alat yang digunakan adalah gelas ukur (10, 100 dan $500 \mathrm{~mL}$ ), botol vial (bening dan gelap), pipet tetes, corong kaca, pipet volum 1 $\mathrm{mL}$, rotari vakum evaporator, corong buchner, pompa vakum, labu ukur $25 \mathrm{~mL}$, sendok zat, $\mathrm{pH}$ 
meter, seperangkat alat spektrofotometer UVVis PerkinEImer L850 dan alat-alat gelas umum lainnya.

\section{Prosedur Penelitian}

\section{Preparasi sampel (Yudiono, 2011)}

Bayam merah yang diperoleh dibersihkan kemudian dicuci dengan air mengalir. Daun bayam merah dipotong-potong dan siap untuk diekstraksi.

\section{Ekstraksi bayam merah (Yudiono, 2011)}

Metode ekstraksi dilakukan dengan maserasi selama 2 kali 24 jam. Potongan daun bayam merah ditimbang sebanyak $500 \mathrm{~g}$ lalu dimasukan ke dalam wadah kedap cahaya, selanjutnya ditambahkan $1000 \mathrm{~mL}$ etanol 96\% dengan rasio perbandingan sampel dan pelarut $1: 2(b / v)$, lalu ditutup rapat. Kemudian disaring menggunakan corong buchner dengan bantuan pompa vakum untuk memisahkan ekstrak dari residu. Ekstrak yang didapatkan kemudian dipisahkan dari pelarutnya dengan menggunakan rotari vakum evaporator

\section{Penentuan panjang gelombang maksimum (Yudiono, 2011)}

Diambil $1 \mathrm{~mL}$ ekstrak etanol bayam merah lalu dimasukan ke dalam labu ukur $25 \mathrm{~mL}$ kemudian ditambahkan akuades sampai tanda batas. Kemudian ditentukan panjang gelombang maksimum menggunakan spektrofotometer UV-Vis.

\section{Penentuan absorbansi awal (Yudiono, 2011)}

Diambil $4 \mathrm{~mL}$ ekstrak etanol bayam merah lalu dimasukan ke dalam labu ukur $100 \mathrm{~mL}$ kemudian ditepatkan dengan akuades untuk pengujian penetapan nilai absorbansi awal dan ditambahakan masing-masing larutan buffer $\mathrm{pH}$ 2-5 untuk pengujiaan stabilitas $\mathrm{pH}$. Kemudian diukur absorbansinya menggunakan spektrofotometer UV-Vis.
Uji stabilitas ekstrak bayam merah terhadap pengaruh ph selama masa penyimpanan (Yudiono, 2011)

Diikur $4 \mathrm{~mL}$ ekstrak bayam merah lalu dimasukan ke dalam masing-masing 4 labu ukur $100 \mathrm{~mL}$ lalu ditambahkan larutan penyangga yang telah disediakan pada masing-masing labu ukur secara berturut-turut yaitu buffer $\mathrm{pH}$ 2, 3, 4 dan 5. Kedalam masingmasing botol vial diisi dengan larutan dari labu ukur sesuai dengan $\mathrm{pH}$ masing-masing botol yang tersedia dan diletakan pada suhu ruang. Sampel disimpan selama masa penyimpanan 7 hari dan diukur absorbansinya pada panjang gelombang maksimun setiap 24 jam sekali menggunakan spektrofotometer UV-Vis. Perlakuan dilakukan sebanyak dua kali. Lalu menghitung degradasi zat warna dengan menggunakan Persamaan 1.

$$
\text { Degradasi }(\%)=\frac{\text { Ao-At }}{\text { Ao }} \times 100
$$

Dimana :

$A_{0}=$ absorbansi sebelum dilakukan pengujian At $=$ absorbansi per satuan waktu

Uji stabilitas ekstrak bayam merah terhadap paparan sinar matahari selama masa penyimpanan (Yudiono, 2011)

Disiapkan 4 botol vial gelap dan 4 botol vial bening. Masing-masing botol vial diisi dengan ekstrak bayam merah yang telah diencerkan dalam labu ukur dengan menambahkan akuades sampai tanda batas. Kemudian masing-masing botol diletakan di luar ruangan agar terpapar sinar matahari. Paparan sinar matahari berlangsung selama 4 jam. Setiap 1 jam selama 4 jam diambil 1 botol vial bening dan botol vial gelap. Kemudian dilakukan pengukuran absorbansi dengan spektrofotometer UV-Vis. Perlakuan dilakukan sebanyak dua kali. Lalu menghitung degradasi zat warna dengan Persamaan 2. 
Degradasi $(\%)=\frac{\text { Ao-At }}{A o} \times 100$

Dimana :

$A_{0}=$ absorbansi sebelum dilakukan pengujian

At $=$ absorbansi per satuan waktu

\section{HASIL DAN PEMBAHASAN}

\section{Ekstrak Zat Warna Alami Bayam Merah}

Ekstraksi dengan metode maserasi dipilih karena lebih praktis, pelarut yang digunakan lebih sedikit, hanya waktu yang dibutuhkan relatif lebih lama. Hasil ekstraksi di peroleh ekstrak berwana ungu kemerah-merahan. Menurut Andersen et al. (2001) dalam Wulaningrum (2013), salah satu pigmen yang dapat diekstrak dari sumber bahan alami adalah antosianin yang termasuk golongan senyawa flavonoid. Pigmen ini berperan terhadap timbulnya warna merah hingga biru pada beberapa bunga, buah, daun dan umbi.

\section{Stabilitas Ekstrak Bayam Merah Terhadap Pengaruh pH Selama Masa Penyimpanan}

Uji stabilitas zat warna alami terhadap pengaruh $\mathrm{pH}$ dilakukan dengan ekstrak daun bayam dengan menambahkan larutan buffer dengan masing-masing $\mathrm{pH} 2,3,4$ dan 5 . kemudian di ukur absorbansinya setiap hari selama masa penyimpanan 7 hari.

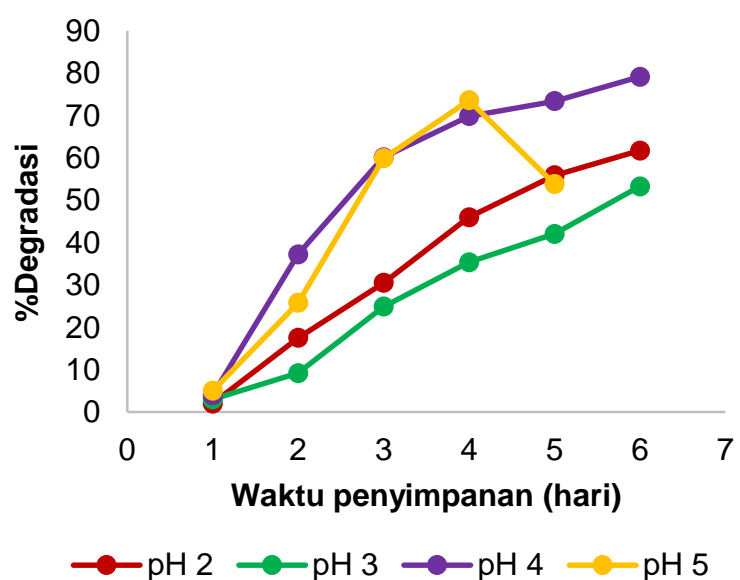

Gambar 1. Degradasi zat warna terhadap pengaruh $\mathrm{pH}$ selama masa penyimpanan
Berdasarkan data yang diperoleh, diketahui degradasi tertinggi pada $\mathrm{pH} 4$, yaitu $79,07 \%$ (Gambar 1). Pada pH 5 di hari ke empat mencapai degradasi $73,54 \%$ dan mengalami kerusakan pada hari penyimpanan setelahnya. Degradasi pigmen antosianin terendah di peroleh pada $\mathrm{pH} 3$, yaitu 53,23\%. Perbedaan degradasi $\mathrm{pH} 2$ dan $\mathrm{pH} 3$ tidak signifikan, sedangkan $\mathrm{pH} 4$ dan $\mathrm{pH} \quad 5$ mengalami degradasi warna yang sangat tajam (Gambar 1).

Masing-masing $\mathrm{pH}$, mulai dari $\mathrm{pH} 2,3,4$, dan 5 mengalami degradasi yang berarti bahwa suasana asam yang berbeda mempengaruhi kestabilan zat warna bayam merah. Sementara itu, pada $\mathrm{pH}$ yang lebih rendah ( $\mathrm{pH} 2$ dan 3), zat warna cenderung lebih stabil. $\mathrm{Hal}$ ini membuktikan bahwa suasana asam yang berbeda berpengaruh terhadap kestabilan antosianin. Menurut (Farida \& Nisa, 2014), pada pengujian stabilitas antosianin dari range $\mathrm{pH} 1-5, \mathrm{pH} 3$ mengalami penuruan paling sedikit artinya $\mathrm{pH}$ paling stabil terdapat pada $\mathrm{pH}$ 3 , sedangkan pada $\mathrm{pH} 4$ dan 5 mengalami penurunan secara tajam. Rundubelo et al. (2019) dan Sampebarra (2018), melaporkan bahwa penggunaan $\mathrm{pH}$ rendah dapat meningkatkan kestabilan pigmen antosianin ubi banggai, proses tersebut terjadi karena senyawa antosianin akan membentuk kation flavilium berwarna merah pada $\mathrm{pH}$ rendah dan pada $\mathrm{pH}$ tinggi terjadi deprotonisasi serta hidrasi kation flavilium menjadi karbinol yang berwarna pudar atau tidak berwarna lagi.

\section{Stabilitas Ekstrak Bayam Merah Terhadap Paparan Sinar Matahari Selama Masa Penyimpanan}

Paparan sinar matahari juga mempengaruhi stabilitas pigmen ekstrak bayam merah. Pengujian dilakukan dengan 
lama paparan 4 jam dan pengamatan dilakukan setiap 1 jam menggunakan botol vial bening dan gelap. Dari hasil uji stabilitas terhadap paparan sinar matahari diketahui tingkat degradasi pada botol vial bening sebesar $48,78 \%$ dan pada botol vial gelap sebesar $31,70 \%$ (Gambar 2).

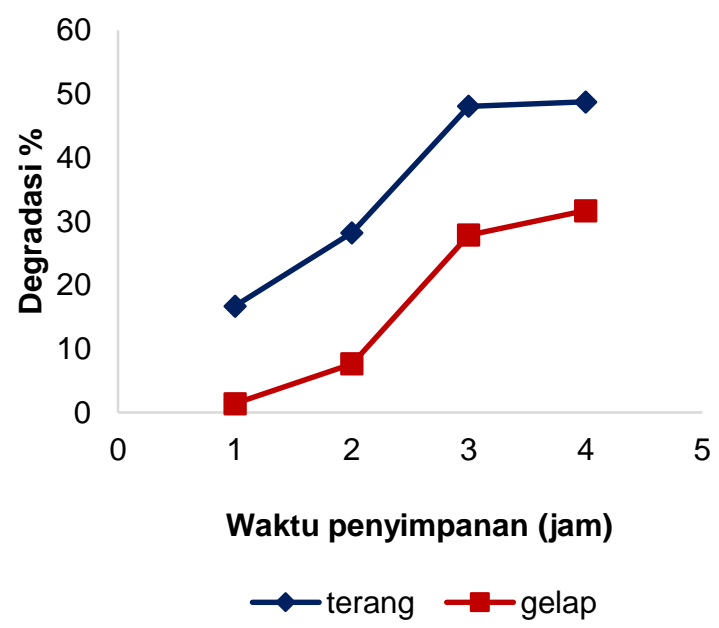

Gambar 2. Degradasi zat warna terhadap paparan sinar matahari selama masa penyimpanan

Setelah dilakukan pengujian pada sampel botol bening dan botol gelap, terjadi peningkatan degradasi pada setiap jam pemaparan sinar matahari. Hal ini menandakan paparan sinar matahari dapat memepengaruhi kestabilan zat warna, semakin lama penyinaran terhadap sampel menyebabkan warna semakin memudar.

Degradasi sampel pada wadah berwarna bening memiliki tingkat degradasi yang lebih tinggi di bandingkan dengan botol sampel berwarna gelap. Hal ini menunjukan botol gelap dapat menghambat sinar UV lebih baik dibandingkan botol sampel berwarna bening. Waktu pemaparan juga mempengaruhi kestabilan zat warna bayam merah, dimana semakin lama pemaparan sinar matahri semakin tinggi degradasi warna pada sampel. Paparan sinar matahari merupakan salah satu faktor yang dapat mempengaruhi stabilitas zat warna. Sinar matahari merupakan salah satu kondisi yang menyebabkan terjadinya perubahan warna. Jika diamati benda-benda yang terkena paparan sinar matahari secara langsung cenderung lebih cepat mengalami kerusakan.

Hal ini dapat dijelaskan karena matahari adalah sumber sinar utama untuk bumi dan atmosfir yang memiliki besaran energi. Energi ini diserap oleh ekstrak sehingga menyebabkan warna berubah ke panjang gelombang yang lebih pendek. Penjelasan ini sesuai dengan penelitian Samsudin \& Khoiruddin (2009), sinar matahari mengandung energi yang disebut energi insolasi. Insolasi ini tediri atas sinar-sinar radiasi yang tersusun dari bermacam-macam panjang gelombang. Sinar dengan panjang gelombang lebih pendek akan menghasilkan efek fitokimia tertentu dan mampu mempercepat proses oksidasi biomolekul juga proses kematangan buah.

\section{KESIMPULAN}

Berdasarkan hasil penelitian yang dilakukan dapat disimpulkan bahwa pada masing-masing variasi $\mathrm{pH} 2,3,4$, dan 5 stabilitas zat warna menurun selama penyimpanan. Penurunan tertinggi pada $\mathrm{pH} 4$ sebesar $79,07 \%$ dan terendah pada $\mathrm{pH} 3$ sebesar 53,23 \%. Paparan sinar matahari selama 4 jam ekstrak bayam merah mengalami penurunan tertinggi pada botol vial bening sebesar $48,78 \%$ dibandingkan dengan botol vial gelap sebesar $31,70 \%$.

\section{DAFTAR PUSTAKA}

Akhda, D. (2009). Pengaruh Dosis dan Waktu Aplikasi Kompos Azolla sp terhadap Pertumbuhan Tanaman Bayam Merah (Alternanthera amoena Voss) [Skripsi]. UIN Maulana Malik Ibrahim, Malang. 
Bangee, O. D., Wilson, V. H., East, G. C., \& Holme, I. (1995). Antioxidant-induced yellowing of textiles. Polymer Degradation and Stability, 50(3): 313-317. https://doi.org/10.1016/01413910(95)00156-5

Farida, R., \& Nisa, F. C. (2014). Ekstraksi Antosianin Limbah Kulit Manggis Metode Microwave Assisted Extraction (Lama Ekstraksi dan Rasio Bahan: Pelarut). Jurnal Pangan Dan Agroindustri, 3(2): 362-373.

Jenie, B., Helianti, \& Fardiaz, S. (1994). Pemanfaatan Ampas Tahu, Ongkok, dan Dedak Untuk Produksi Pigmen Merah oleh Monascus purpureus. Buletin Teknologi Dan Industri Pangan, 22-24.

Kristamtini, Taryono, T., Basunanda, P., \& Murti, R. (2014). Keragaman Genetik dan Korelasi Parameter Warna Beras dan Kandungan Antosianin Total Sebelas Kultivar Padi Beras Hitam Lokal. IImu Pertanian, 17(1): 57-70. https://doi.org/10.13140/2.1.5061.6964

Moss, B. (2002). The Chemistry of Food Colour. Didalam: D.B. MacDougall, Editor. 2002. Colour in Food: Improving Quality. CRC Press, Washington.

Pan, J.-Q., Liu, N. C., \& Lau, W. W. Y. (1998). Preparation and properties of new antioxidants with higher MW. Polymer Degradation and Stability, 62(1): 165-170. https://doi.org/10.1016/S01413910(97)00274-7

Pratiwi, A. (2017). Effect of nitrogen fertilizer to the flavonoid content of red amaranth (Amaranthus gangeticus L.). Pharmaciana, 7(1): 87-94. https://doi.org/10.12928/pharmaciana.v7i 1.4213

Pushpa, S. A., Goonetilleke, P., \& Billingham, N. C. (1995). Diffusion of Antioxidants in Rubber. Rubber Chemistry and Technology, 68(5): 705-716. https://doi.org/10.5254/1.3538767

Rundubelo, B. A., Ridhay, A., Hardi, J., \& Pusptasari, D. J. (2019). Uji Stabilitas Pigmen Ekstrak Ubi Banggai (Dioscorea bulbifera var celebica Burkill) Pada
Berbagai Variasi Ph Dan Lama Paparan Sinar Matahari. KOVALEN: Jurnal Riset Kimia, 5(1): 9-16.

Sampebarra, A. L. (2018). Karakteristik Zat Warna Antosianin Dari Biji Kakao NonFermantasi Sebagai Sediaan Zat Warna Alam. Jurnal Industri Hasil Perkebunan, 13(1): 63-70. https://doi.org/10.33104/jihp.v13i1.3880

Samsudin, A. M., \& Khoiruddin, K. (2009). Ekstraksi, Filtrasi Membran Dan Uji Stabilitas Zat Warna Dari Kulit Manggis (Garcinia mangostana) [Makalah Penelitian]. Universitas Diponegoro, Semarang. http://eprints.undip.ac.id/763/1/makalah_p enelitian_asep_(L2C005239)Khoiruddin(L2C005271).pdf

Suzery, M., Lestari, S., \& Cahyono, B. (2010). Penentuan Total Antosianin Dari Kelopak Bunga Rosela (Hibiscus Sabdariffa L) Dengan Metode Maserasi Dan Sokshletasi. Jurnal Sains dan Matematika Universitas Diponegoro, 18(1): 1-6.

Syaifuddin. (2015). Uji Aktivitas Antioksidan Bayam Merah (Alternanthera amoena Voss.) Segar dan Rebus Dengan Metode DPPH (1,1 -diphenyl-2picylhydrazyl) [Skripsi]. UIN Walisongo, Semarang.

Wulaningrum, R. A. (2013). Pengaruh Asam Organik Dalam Ekstraksi Zat Warna Kulit Buah Manggis (Garcinia mangostana). Indo. J. Chem. Sci., 2(2): 119-124.

Yudiono, K. (2011). Ekstraksi Antosianin Dari Ubijalar Ungu (Ipomoea batatas Cv. Ayamurasaki) Dengan Teknik Ekstraksi Subcritical Water. Teknologi Pangan: Media Informasi dan Komunikasi IImiah Teknologi Pertanian, 2(1). https://doi.org/10.35891/tp.v2i1.479 